\title{
Maize seedling emergence in response to climatic variability in a tropical rainforest area
}

\author{
Chris Adegoke FAYOSE ${ }^{1,2, \star}$ and Morakinyo Abiodun Bamidele FAKOREDE ${ }^{2}$
}

Received February 25, 2021; accepted April 12, 2021.

Delo je prispelo 25. februarja 2021, sprejeto 12. aprila 2021.

\begin{abstract}
Maize seedling emergence in response to climatic variability in a tropical rainforest area

Abstract: Environmental factors causing low seedling emergence often observed in tropical maize (Zea mays L.) are poorly documented. This study was conducted to investigate the effects of weather factors on maize seedling emergence at the Obafemi Awolowo University Teaching and Research Farm (OAU TRF). Five maize varieties sown weekly, in 3-replicate RCBD experiments throughout the 2016 and 2017 cropping seasons, were used to monitor emergence percentage (E \%), emergence index (EI) and emergence rate index (ERI). Climatic data were obtained from the automatic weather station located on the farm. Analysis of variance revealed highly significant ( $\mathrm{P}$ $\leq 0.01)$ environmental effect for all traits. Soil moisture $(\mathrm{Sm})$, relative humidity, air temperature, heat unit and soil heat flux (SHF) showed significant $(\mathrm{P} \leq 0.05)$ correlation coefficients with all traits, but there was no relationship between the emergence traits and grain yield. Stepwise multiple regression and sequential path coefficient analyses indicated that increased $\mathrm{Sm}$, rather than rainfall per se, increased the speed of emergence. Minimum air temperature and SHF with direct effects, and heat unit with indirect effect, negatively affected emergence the most. Relatively low Tmin and SHF, along with just enough Sm maximized seedling emergence in the rainforest agro-ecology of southwestern Nigeria.
\end{abstract}

Keywords: climatology; crop phenology; growth analysis; seedling vigour; Zea mays $\mathrm{L}$.

\section{Vpliv sprememb podnebja na vznik kalic koruze na območju tropskega deževnega gozda}

Izvleček: Okoljski dejavniki, ki vplivajo na slab vznik koruze (Zea mays L.) so v tropskih razmerah pogosto opaženi a slabo dokumentirani. Ta raziskava je bila izvedena za preučevanje učinkov dejavnikov podnebja na vznik koruze na univerzitetnem učnem in raziskovalnem posestvu Obafemi Awolowo (OAU TRF), Nigerija. Pet sort koruze je bilo posejanih tedensko $s$ tremi ponovitvami $\mathrm{v}$ popolnem naključnem bločnem poskusu (RCBD) v rastnih sezonah 2016 in 2017. Pri tem so bili spremljani odstotek kalitve (E \%), indeks vznika (EI) in hitrost vznika (ERI). Klimatski podatki so bili pridobljeni iz avtomatske vremenske postaje na posestvu. Analiza variance je pokazala zelo značilne $(\mathrm{P} \leq 0,01)$ okoljske vplive na vse opazovane lastnosti. Vlažnost tal $(\mathrm{Sm})$, relativna vlažnost zraka, temperatura zraka, privzem toplote in tok toplote $\mathrm{v}$ tleh (SHF) so imeli značilno korelacijo $(\mathrm{P} \leq 0,05) \mathrm{z}$ vsemi opazovanimi lastnostmi, ugotovljena pa ni bila nobena povezava med lastnostimi kalitve in pridelkom zrnja. Stopenjska multipla regresija in kasnejša analiza posrednih in neposrednih vplivov na kalitev sta pokazali, da je imela nanjo večji vpliv vlažnost tal, ki je povečala hitrost kalitve kot pa sama količina padavin. Minimalna temperatura zraka in dotok toplote $\mathrm{v}$ tla sta imela največji neposredni vpliv na kalitev. Nizka temperature tal (Tmin) in majhen dotok toplote $\mathrm{v}$ tla (SHF) sta ob ravno zadostni vlažnosti tal (Sm) maksimalizirali vznik koruze v agro-ekoloških razmerah deževnega gozda jugozahodne Nigerije.

Ključne besede: klimatologija; fenologija poljščin; rastna analiza; vigor sejank; Zea mays L.

1 Department of Agricultural Technology, Ekiti State College of Agriculture and Technology, Isan Ekiti, Nigeria.

2 Department of Crop Production and Protection, Obafemi Awolowo University, Ile-Ife, Nigeria.

* Corresponding author: +2348060365729, adegoke_chris@yahoo.com 


\section{INTRODUCTION}

The demand for maize (Zea mays L.) grains in subSaharan Africa (SSA) has continued to increase because of its importance in human food, livestock feed, and industrial raw material. Maize accounts for more than $15 \%$ of the total calorie intake by the population in SSA, along with its use in animal feed production and as raw material in some agro-allied industries. As noted by Talabi et al. (2017), better adaptation of maize crop to various agro-ecologies, responsiveness to fertilizer application, and relative ease of cultivation, processing and storage has greatly increased its popularity in West and Central Africa (WCA) over other traditional cereal crops, such as sorghum [Sorghum bicolor (L.) Moench] and pearl millet (Penisetum typhoides L.). There is, therefore, an urgent need for increased maize production in these regions to meet the constant demand for its grains. Environmental factors such as poor soil conditions, especially decreasing nitrogen level, drought, increased urbanization, poor or inaccurate agronomic practices, and poor climatic conditions have affected maize production, limiting it from attaining the desired production levels, despite maize crop improvements over the years from active breeding programs.

FAO (2016) puts maize production in Nigeria at about $11 \mathrm{MT} /$ year compared to $384 \mathrm{MT} /$ year obtained in the USA. A combination of improved varieties, improved agronomic practices and production intensification, including adaptation of maize production to climate through adequate knowledge of crop response to the variability of climatic conditions throughout the life cycle of the crop will be necessary to close this huge yield gap to a reasonable level. High emergence percentage followed by high seedling vigour and vigorous vegetative growth are necessary conditions for high final stand of the crop on the field which, in turn, leads to higher grain yield.

Maize, for all its positive features, depends on the environment for its survival; the climatic conditions constitute a very important component of the environment. Unfortunately, the information available on maize crop response to climate is very few and fewer still at the seedling stage, especially in the rainforest agro-ecology of Nigeria, and where such information exists, the depth and therefore the accuracy is often in question. This is due to the the use of rather outmoded climatology items of equipment for such studies compared with improved equipment with greater accuracy used in the developed world (Fakorede and Opeke 1985). Furthermore, there are often inadequacies in the number of climatic variables analyzed, or statistical analyses used, or both. Consequently, moisture availability has generally been seen as the most important variable influencing maize growth at seedling and flowering stages, even though there is paucity of information about maize crop response to other climatic variables such as temperature, heat unit and soil heat flux at the seedling stage of maize growth. Awosanmi et al. (2016) found significant effect of moisture stress on tropical maize seed yield in the rainforest ecology of Southwest Nigeria. Oke (2016) found that yield had significant positive correlations with total rainfall and air mean relative humidity and negative correlations with air temperature extremes in similar climate. Tunde et al. (2011) also found maize production to be highly inflenced by rainfall, air relative humidity, number of rainy days and air temperature at Ilorin, a Southern Guinea savanna location in Nigeria. Ammani et al. (2012) found that drought occuring at about one week before flowering to the grain filling stage caused significant reduction in yield when they evaluated the relationship between rainfall and maize crop production in the savannah ecologies. These studies have involved few climatic variables, mostly employed correlation for data analysis and none actually investigated crop response to climatic factors at the seedling stage. The study by Fakorede and Opeke (1985) employed several climatic variables and statistical analysis methods to elucidate the response of maize yield to weather factors in the rain forest of Nigeria, typified by Ile-Ife. They found significant negative correlation coefficients of effective rainfall with grain yield and air relative humidity even though the study was limited by the rather outmoded climatological equipment used. Studies conducted in advanced countries, such as that by Jong et al. (1982) concluded that solar radiation was the single most influencial climatic factor affecting yield and its components in maize even though only air temperature and solar radiation were the focus of analysis in the study. Dimpsey (1995) found $16{ }^{\circ} \mathrm{C}$ to $35{ }^{\circ} \mathrm{C}$ as the optimum germination range for maize seeds when he studied the effect of air temperature on the germination of different seeds in Australia. Alm et al. (1993) found a positive correlation between air temperature (from $10^{\circ} \mathrm{C}$ to $25^{\circ} \mathrm{C}$ ) and seedling elongation of maize and soybean (Glycine $\max \mathrm{L}$ ).

Rainfall is the primary climatic factor that determines the timing of most agronomic practices, especially planting operations in Nigeria. False start of rainfall and unpredictable frequent occurrence of short duration drought during the growing season, both of which have become more severe over time, are now features of the rainforest agro-climatic zone of SW Nigeria typified by Ile-Ife, a location at $7^{\circ} 28^{\prime} \mathrm{N}, 4^{\circ} 33^{\prime} \mathrm{E}$ and $244 \mathrm{~m}$ asl in the zone (Fayose and Fakorede, 2021). Such weather anomalies have been attributed to climate change (Fakorede and Akinyemiju, 2003). The year 2020 received one of the smallest total rainfall amounts $(<700 \mathrm{~mm})$ in recent 
times, next to just above $700 \mathrm{~mm}$ received in 2017 at the location. Low amount of rainfall was received in June and July when frequent, heavy rainfall is normally expected. Reduced seedling emergence and low vigor, are usually associated with the weather anomalies that characterize maize especially those planted early in the zone. This has often resulted in missing stands, and the situation has been aggravated by climate change in recent times. It is therefore necessary to have adequate knowledge of crop response to climatic variables at all stages in order to be able to cope with the negative impacts of climate change.

The primary objective of this study was to identify the climatic factors influencing seedling emergence of maize under the natural climatic conditions of the rainforest agro-ecology of SW, Nigeria. A secondary objective was to determine the relationship of the seedling emergence traits with grain yield of maize.

\section{MATERIAL AND METHODS}

The study was conducted at the Teaching and Research Farm of Obafemi Awolowo University, Ile-Ife (OAU TRF) in the 2016 and 2017 early and late cropping seasons. OAU TRF is located at $7^{\circ} 28^{\prime} \mathrm{N}, 4^{\circ} 33^{\prime} \mathrm{E}$ and 244 $\mathrm{m}$ above sea level in the marginal areas of the rainforest agro-ecology of South Western Nigeria. As a typical rainforest agro-ecological location, Ile-Ife is characterized by two contrasting rainy seasons; the first or early season from about March/April to July and the second or late season from late August to October with a period of short dry spell that occurs in July/August, popularly referred to as the "August break" or "August dry spell". Total annual range of $740 \mathrm{~mm}$ to $2040 \mathrm{~mm}$ has been reported at the location, along with a mean maximum temperature range of $29^{\circ} \mathrm{C}$ to $32^{\circ} \mathrm{C}$ (Fakorede and Akinyemiju, 2003).

Five maize varieties adapted to the tropical rainforest environments were sown in three replicate-randomized complete block design. They include four openpollinated varieties White DT STR SYN1.- TZL Comp. 1 - W, ACR 94 TZE Comp $5 \mathrm{C}_{3}$, TZL Comp. 4 DT F, TZL Comp. 1 C6/DT - SYN - $1-\mathrm{W}$ all of which were developed at the International Institute of Tropical Agriculture (IITA), Ibadan; and a hybrid, 'Oba Super 1', obtained from Premier Seeds, Zaria. All the varieties are white-grained, high yielding and have been released for commercial production in Nigeria and several other West and Central African (WCA) countries.

The maize was sown weekly from March to November each year. However, there were some weeks when sowing could not be done due to some extraneous factors; therefore, data from 54 dates (DOS) were analysed for seedling emergence and vigour and 42 dates were analysed for grain yield. Each plot contained four or six rows, which were $5 \mathrm{~m}$ long spaced $0.75 \mathrm{~m}$ apart; within row spacing was $0.5 \mathrm{~m}$. Each plot was about $15 \mathrm{~m}^{2}$ and $22.5 \mathrm{~m}^{2}$ for the four and six-row plots, respectively. Three seeds were sown per hill. Prior to sowing, the experimental land was ploughed and harrowed, and the seed were treated with thiamethoxam, mefenoxam (metalaxyl-M) and difenoconazole, to control damage by soil-borne diseases and insect pests. Weeds were controlled by the application of post-sowing and pre-emergence of maize with primextra, which contains atrazine (2-chloro-4(ethyl amino)-6-isopropylamino-s-triazine) and alachlor (N-(methyl-2-methoxy-ethyl)-2-ethyl-8-methyl-chloroacetanilide) as active ingredients at the rate of $5 \mathrm{l} / \mathrm{ha}$. Emergence counts were made daily from five to nine days after sowing (DAS); from which emergence percentage (E\%), emergence index (EI), and emergence rate index (ERI) were computed as follows (Fakorede and Agbana 1983):

$$
\begin{aligned}
& E \%=\frac{\text { Seedlings emerged in } X \text { DAP }}{\text { Total no. of seeds sown }} * 100 \\
& E I=\frac{\sum(\text { Plants emerged in a day }) *(D A P)}{\text { Plants emerged } 9 \text { DAP }} \\
& E R I=\frac{E I}{E \% \text { at } 9 D A P} * 100
\end{aligned}
$$

Thinning was done immediately after emergence count at 9 DAS to two plants per stand giving an estimated plant population density of 53,333 plants ha ${ }^{-1}$. Fertilizer was applied immediately after thinning at the rate of $60 \mathrm{~kg} \mathrm{ha}^{-1}$ each for $\mathrm{N}, \mathrm{P}_{2} \mathrm{O}_{5}$ and $\mathrm{K}_{2} \mathrm{O}$. Further weed control was done using paraquat ( $\mathrm{N}, \mathrm{N}^{\prime}$-dimethyl-4,4'bipyridinium dichloride), carefully applied as a postemergence, non-selective and contact herbicide at the rate of $3.0 \mathrm{l} \mathrm{ha}^{-1}$.

Data collected on grain yield were adjusted to 15 $\%$ moisture content. Minimum and maximum air temperatures and air relative humidity, rainfall, solar radiation, net radiation, wind speed, soil temperatures and soil heat flux were monitored at the automatic weather station (AWS), OAU MET Station, of the Atmospheric Physics Research Group located on the OAU TRF. The experimental plots were within $100-500$ meters of the weather station mostly in plain sight except for the last four environment in 2016 that had a slightly dense vegetation inbetween. Most sensors (Table 1) at the station were manufactured by Campbell Scientific Inc., USA. 
Table 1: Weather tracking sensors and their level of accuracy and output units at the automatic weather station of the OAU MET Station within the OAU TRF.

\begin{tabular}{|c|c|c|c|}
\hline Weather variable & Tracking sensor & Accuracy & Output unit \\
\hline Solar radiation & CS 300 Pyranometer & $\pm 5 \%$ & $\mathrm{~W} \mathrm{~m} \mathrm{~m}^{-2}$ \\
\hline Net radiation & NR-LITE Radiometer & $\pm 5 \%$ & $\mathrm{~W} \mathrm{~m} \mathrm{~m}^{-2}$ \\
\hline Air temperature/ & HMP45 Temperature and & & ${ }^{\circ} \mathrm{C}$ (Temperature) \\
\hline Relative Humidity & Humidity Probe & $\pm 2-3 \%$ & $\%$ (Relative humidity) \\
\hline Soil temperature & Model 108 Soil Temperature Probe & $\pm 0.3^{\circ} \mathrm{C}$ to $0.7^{\circ} \mathrm{C}$ & ${ }^{\circ} \mathrm{C}$ \\
\hline Soil heat flux & Model HFP01 Soil Heat Flux Plate & -15 to $5 \%$ & $\mathrm{Wm}^{-2}$ \\
\hline Wind speed & A100L Cup Anemometer & $\pm 0.1 \mathrm{~m} \mathrm{~s}^{-1}$ & $\mathrm{~m} / \mathrm{s}$ \\
\hline Rainfall & TE525 Tipping Bucket Rain Gauge & $\begin{array}{l} \pm 1 \% \text { (for up to } 1 \text { inch per hour) } \\
-3 \text { to } 0 \% \text { (for } 1 \text { to } 2 \text { inches per hour) } \\
-5 \text { to } 0 \% \text { (for } 2 \text { to } 3 \text { inches per hour) }\end{array}$ & $\mathrm{mm}$ \\
\hline
\end{tabular}

They are popular for designing weather tracking systems that operate in vast array of climates including those specific for the tropical hot and humid climate with high level of sensitivity and precision. Heat unit was computed from the minimum and maximum temperature per day as given below:

$$
H U=\sum_{i=1}^{n}\left(\frac{X i^{H}+X i^{L}}{2}\right) 10
$$

where $\mathrm{X}_{\mathrm{i}}^{\mathrm{L}}$ is the daily minimum air temperature $\left({ }^{\circ} \mathrm{C}\right), \mathrm{X}_{\mathrm{i}}^{\mathrm{H}}$ is the daily maximum air temperature $\left({ }^{\circ} \mathrm{C}\right)\left(\mathrm{X}_{\mathrm{i}}^{\mathrm{H}}\right.$ $=30$ if $\mathrm{X}_{\mathrm{i}}^{\mathrm{H}}>30^{\circ} \mathrm{C}, \mathrm{X}_{\mathrm{i}}^{\mathrm{H}}=\mathrm{X}_{\mathrm{i}}^{\mathrm{H}}$ if $\left.\mathrm{X}_{\mathrm{i}}^{\mathrm{H}} \leq 30^{\circ} \mathrm{C}\right)$, and $10^{\circ} \mathrm{C}$ is the base temperature (Abasi et al., 1985).

Prior to analysis, percentage data were transformed using the square root method; while soil moisture data were subjected to $\log \left(\log _{\mathrm{e}}\right)$ transformation. Analysis of variance was done on all data using PROC GLM of Statistical Analysis System (SAS, 2000). The linear additive model for the ANOVA was: $Y_{i j k}=\mu+\alpha_{i}+\beta_{j(i)}+\lambda_{k}+\alpha \lambda_{(i k)}$ $+\varepsilon_{i j k}$ in which $Y_{i j k}$ is the observed measurement of the $k^{\text {th }}$ genotype grown in the $j^{\text {th }}$ rep under the $i^{\text {th }}$ environment; $\mu$ is the grand mean; $\alpha_{i}$ is the main effect of the $i^{\text {th }}$ environment, $i=1,2, \ldots . ., 42$ or $54 ; \beta_{j(i)}$ is the effect of the $j^{\text {th }}$ replication nested within the $i^{\text {th }}$ environment, $j=1,2,3$; $\lambda_{k}$ is the effect of the $k^{\text {th }}$ genotype, $\mathrm{k}=1,2, \ldots .5 ; \alpha \lambda_{(i k)}$ is the first order interaction of the $i^{\text {th }}$ environment with the $k^{\text {th }}$ geno- type, and $\varepsilon_{i j k}$ is the random error (residual) term. Furthermore, correlation and regression analyses were done to determine the trends in maize seedling response to weather variables. Emergence traits were regressed on weather variables in linear model: $Y=a+b X$ and polynomial model: $Y=a+b_{1} X^{1}+\ldots b n X^{n}, Y$ and $X$ are the emergence traits and weather variable(s), respectively; a and $b$ are the intercept and regression coefficient, respectively; $\mathrm{n}$ is the order of the polynomial (quadratic, cubic, quartic). Correlation analysis was done where the coeffi-

$$
\text { cient } \boldsymbol{r}=\frac{\Sigma(X-\bar{x})(\mathbf{Y}-\bar{Y})}{\sqrt{[\Sigma(X-\bar{x}) 2 * \Sigma(Y-\bar{Y}) 2]}} \text {. }
$$

Path analysis is an extension of multiple regression, particularly step-wise multiple regression analysis which, along with sequential path diagrams, was employed to elucidate the cause and effect relationships among traits. The Statistical Package for the Social Sciences (SPSS Inc, 2007) was used for the stepwise regression analyses to provide information on the path coefficients and the causal relationships required for the path diagrams. The procedure, which was described by Mohammadi et al. (2003), has been used by Badu-Apraku et al. (2014) and Talabi et al. (2017). The predictor variables which, in this case, were weather factors, were organized into first, second, and third order, based on their contributions to the total variation in emergence traits with minimized multi collinearity. To perform the stepwise regression analysis, emergence traits were regressed on climatic variables to identify the ones with significant contribu- 
tions to the variation in the traits at $p \leq 0.05$, and they were categorized as first order variables. The first-order variables thereafter were each regressed on other climatic variables which were not in the first order category, to identify the climatic variables with significant contributions to emergence traits through the first-order variables. These variables were classified as second order variables. The same procedure was repeated to identify third order variables(s) and so on. The path coefficients were obtained from the standardized $b$-values of the stepwise regression analysis. The path coefficients were tested for significance using the standard errors at 0.05 probability level. Only traits having significant path coefficients were retained in each order.

\section{RESULTS}

Results from the combined ANOVA for grain yield and seedling emergence traits revealed highly significant effects $(p \leq 0.01)$ for all sources of variation; that is, environment, variety and $\mathrm{Ex} \mathrm{V}$ interaction (Table 2). The effect of replication within environment was also highly significant for all traits except ERI. The coefficient of variation $(\mathrm{CV})$ ranged from about $7 \%$ for EI to about $81 \%$ for ERI. Fairly high $\mathrm{R}^{2}$ value was observed for grain yield
(86 \%) and higher still for $\mathrm{E} \%$ at 5, 7 and 9 DAS (93 to $94 \%$ ), while ERI had the lowest $\mathrm{R}^{2}$ value.

Rainfall had no significant correlation coefficients ( $r$-values) with seedling emergence traits, unlike soil moisture (Sm) and air relative humidity (RH) which, in most cases, had statistically significant $r$-values with the traits (Table 3); the higher the Sm and $\mathrm{RH}$, the higher the emergence percentage, and the faster the rate of emergence. Similarly, radiation had no significant $r$-values with seedling vigour traits, whereas air temperature and heat units (HU) were significantly correlated with the emergence traits; the higher the air temperature and $\mathrm{HU}$, the lower the emergence percentage, and the slower the rate of emergence. A third group of sharp contrasts involved soil temperatures which, except in only two cases, were not significantly correlated with the emergence traits whereas the higher the soil heat flux (SHF), the lower the emergence percentage and rate of emergence (Table 3). As expected, wind speed had no relationship with emergence traits, although it showed a surprising significant negative relationship $(\mathrm{r}=-0.38$ at $p \leq 0.05)$ with ERI. Highly significant correlations were also observed among all seedling emergence and vigour traits but none had significant correlation with grain yield (Table 4).

Table 2: Mean squares from the ANOVA of seedling emergence traits of five maize varieties evaluated in 54 environments at the OAU TRF in 2016 and 2017 seasons.

\begin{tabular}{|c|c|c|c|c|c|c|c|c|}
\hline Sources & DF & E \%_5 $5^{\dagger}$ & E \%_7 & E \%_9 & EI (Days) & ERI (Days) & $\mathrm{DF}$ & Yield $\left(\mathrm{t} \mathrm{ha}^{-1}\right)$ \\
\hline Env (E) & 53 & $2404.88^{\star * *}$ & $4527.06^{* * *}$ & $3256.58^{* * *}$ & $3.55^{\star * *}$ & $941.65^{\star * *}$ & 41 & $7.61^{* * *}$ \\
\hline Rep/Env & 108 & $100.42^{* * *}$ & $324.17^{* * *}$ & $268.92^{* * *}$ & $0.57^{\star * *}$ & 127.98 & 84 & $0.49^{* * *}$ \\
\hline Variety $(\mathrm{V})$ & 4 & $7684.37^{\star * *}$ & $15343.14^{\star * *}$ & $14332.64^{* * *}$ & $7.33^{* * *}$ & $6680.45^{\star * *}$ & 4 & $4.76^{\star * *}$ \\
\hline $\mathrm{E} \times \mathrm{V}$ & 212 & $201.47^{\star * *}$ & $619.56^{* * *}$ & $607.57^{\star * *}$ & $0.37^{\star * *}$ & $475.86^{* * *}$ & 164 & $0.45^{\star * *}$ \\
\hline Error & 432 & 39.02 & 65.54 & 69.59 & 0.21 & 116.46 & 336 & 0.22 \\
\hline Total & 809 & 282.58 & 613.08 & 516.49 & 0.56 & 298.69 & 629 & 0.83 \\
\hline $\mathrm{CV}, \%$ & & 30.01 & 12.89 & 11.97 & 6.90 & 81.11 & & 30.67 \\
\hline $\mathrm{R}^{2}$ & & 0.93 & 0.94 & 0.93 & 0.80 & 0.79 & & 0.86 \\
\hline
\end{tabular}

$* * *$ - F statistic significant at 0.001 level of probability.

CV-Coefficient of variation

$\mathrm{R}^{2}$ - Coefficient of determination

$\dagger$ - E \% $5=$ emergence percentage at 5 days after sowing (DAS), E\%_7 = emergence percentage at 7DASS, E \%_9 = emergence percentage at 9DAS, $\mathrm{EI}=$ emergence index and $\mathrm{ERI}=$ emergence rate index. 
Table 3: Correlation coefficients of seedling emergence traits of five maize varieties with climatic variables obtained for 54 environments at the OAU TRF in 2016 and 2017.

\begin{tabular}{|c|c|c|c|c|c|}
\hline & $\mathrm{E} \% 5^{\dagger}$ & $\mathrm{E} \% \_7$ & E\%_9 & EI & ERI \\
\hline Soil temperature 1 & 0.16 & -0.11 & -0.05 & 0.06 & -0.03 \\
\hline Soil temperature 2 & 0.08 & -0.22 & -0.16 & 0.13 & 0.11 \\
\hline Soil temperature 3 & 0.09 & -0.26 & -0.19 & 0.11 & 0.06 \\
\hline Soil temperature 4 & 0.06 & $-0.33^{*}$ & -0.26 & 0.15 & 0.08 \\
\hline Soil temperature 5 & 0.03 & $-0.37^{\star}$ & -0.30 & 0.17 & 0.09 \\
\hline Soil heat flux & $-0.49^{* *}$ & $-0.64^{\star *}$ & $-0.77^{\star *}$ & $0.33^{\star}$ & $0.44^{* *}$ \\
\hline Soil moisture & $0.38^{\star}$ & $0.62^{\star \star}$ & $0.54^{\star \star}$ & $-0.43^{\star *}$ & $-0.48^{* *}$ \\
\hline Rainfall & 0.01 & 0.22 & 0.20 & 0.01 & -0.24 \\
\hline Wind speed & 0.04 & 0.19 & 0.27 & -0.06 & $-0.38^{\star}$ \\
\hline Mean air temperature & $-0.41^{\star *}$ & $-0.79^{* *}$ & $-0.76^{\star *}$ & $0.38^{\star}$ & $0.43^{\star *}$ \\
\hline Minimum air temperature & $-0.48^{\star *}$ & $-0.82^{\star *}$ & $-0.80^{* *}$ & $0.38^{\star}$ & $0.44^{\star *}$ \\
\hline Maximum air temperature & $-0.39^{*}$ & $-0.67^{\star *}$ & $-0.64^{* *}$ & $0.37^{\star}$ & $0.33^{*}$ \\
\hline Heat unit & $-0.47^{\star \star}$ & $-0.81^{\star *}$ & $-0.80^{* *}$ & $0.36^{\star}$ & $0.44^{* *}$ \\
\hline Mean relative humidity & 0.30 & $0.66^{\star *}$ & $0.65^{\star *}$ & $-0.30^{*}$ & $-0.42^{\star *}$ \\
\hline Minimum humidity & 0.04 & $0.35^{\star}$ & $0.31^{\star}$ & -0.16 & -0.26 \\
\hline Maximum humidiy & $0.48^{\star *}$ & $0.67^{\star \star}$ & $0.67^{\star \star}$ & -0.3 & $-0.34^{*}$ \\
\hline Net radiation & 0.13 & -0.07 & -0.09 & 0.07 & -0.06 \\
\hline Mean global radiation & 0.09 & -0.16 & -0.09 & 0.03 & -0.07 \\
\hline Total global radiation & 0.09 & -0.15 & -0.10 & 0.02 & -0.06 \\
\hline
\end{tabular}

*,**-Significance at 0.05 and 0.01 level of probability, respectively.

${ }^{\dagger}$ - See Table 1.

global solar radiation, net radiation and soil heat flux are in $\mathrm{W} \mathrm{m}^{-2}$; temperature is in ${ }^{\circ} \mathrm{C}$, soil temperatures $1-5$

are soil temperatures at different levels $(2 \mathrm{~cm}, 5 \mathrm{~cm}, 10 \mathrm{~cm}, 20 \mathrm{~cm}$ and $50 \mathrm{~cm}$ for soil temperatures $1,2,3,4$ and

5 , respectively), soil moisture is in $\mathrm{m}^{3} / \mathrm{m}^{3}$, rainfall is in $\mathrm{mm}$, windspeed is in $\mathrm{m} / \mathrm{s}$, relative humidity is in \%.

Table 4: Correlation coefficients of seedling emergence traits of five maize varieties with grain yield of 40 environments at the OAU TRF in 2016 and 2017.

\begin{tabular}{lclllll}
\hline & Mean E_5 & Mean E_7 & Mean E_9 & EI & ERI & Yield $\left(\mathrm{t} \mathrm{ha}^{-1}\right)$ \\
\hline Mean E_5 & 1 & $0.70^{\star *}$ & $0.63^{\star *}$ & $-0.83^{\star *}$ & $-0.68^{\star *}$ & 0.21 \\
Mean E_7 & & 1 & $0.90^{\star *}$ & $-0.70^{\star *}$ & $-0.78^{\star *}$ & 0.24 \\
Mean E_9 & & & 1 & $-0.43^{\star *}$ & $-0.80^{\star *}$ & 0.26 \\
EI & & & & 1 & $0.58^{\star *}$ & -0.10 \\
ERI & & & & 1 & -0.16 \\
Yield (t/ha) & & & & & 1 \\
\hline
\end{tabular}

*,**-Significance at 0.05 and 0.01 level of probability, respectively.

$\dagger$ - See Table 1. 
Table 5: Regression coefficients (b-values), coefficients of determination $\left(R^{2}\right)$ and change in $R^{2}\left(\Delta R^{2}\right)$ from the stepwise multiple regression of maize seedling emergence traits on climatic variables at the OAU TRF in 2016 and 2017.

\begin{tabular}{llll}
\hline Climatic variable & b-value & $\mathrm{R}^{2}$ & $\Delta \mathrm{R}^{2}$ \\
\hline Eoil heat flux ${ }^{\phi}$ & -0.43 & 0.24 & 0.24
\end{tabular}

$\begin{array}{lccc} & \text { E\%_7 } & & \\ \text { Minimum air temperature } & -20.92 & 0.67 & 0.67 \\ \text { Soil moisture } & 34.22 & 0.71 & 0.04 \\ & & & \\ & \text { E\%_9 } & & 0.62 \\ \text { Minimum air temperature } & -6.52 & 0.62 & 0.04 \\ \text { Soil heat flux } & -0.56 & 0.66 & \\ & \text { EI } & & 0.2\end{array}$

\begin{tabular}{llll} 
& \multicolumn{2}{c}{ ERI } & \\
Soil moisture & -154.57 & 0.23 & 0.23 \\
Wind speed & -13.96 & 0.37 & 0.14 \\
Average radiation & -0.07 & 0.43 & 0.07 \\
Minimum humidity & -1.41 & 0.59 & 0.16 \\
Rainfall & 0.08 & 0.63 & 0.04 \\
\hline$\dagger$ - See Table 1. & & \\
$\phi$ - See Table 2 & &
\end{tabular}

Results from the stepwise multiple regression (Table 5) showed that only SHF had a significant effect on $\mathrm{E} \%$ at 5 DAS. The simple linear regression of $\mathrm{E} \%$ at $5 \mathrm{DAS}$ on SHF produced the prediction equation: $\hat{Y}=19.44-$ 0.46X; $\quad\left(\mathrm{R}^{2}=0.24\right)$. This means that for every unit increase in SHF, emergence decreased by $0.46 \%$ with a rather low, though statistically significant $\mathrm{R}^{2}$ value. Stepwise multiple regression analysis showed minimum air temperature $\left(\mathrm{X}_{1}\right)$, followed by $\mathrm{Sm}\left(\mathrm{X}_{2}\right)$ as the most important climatic factors controlling $\mathrm{E} \%$ at 7 DAS. The multiple linear regression produced the prediction equation $\hat{Y}$ $=34.61-20.92 \mathrm{X}_{1}+34.22 \mathrm{X}_{2} ;\left(\mathrm{R}^{2}=0.71\right)$ with minimum temperature accounting for $67 \%$ of the $71 \%$ variations captured by the regression model (Table 3). Emergence $\%$ at 9 DAS was significantly influenced by minimum air temperature $\left(\mathrm{X}_{1}\right)$ and $\operatorname{SHF}\left(\mathrm{X}_{2}\right)$ with the prediction equation $\hat{Y}=169.37-4.12 \mathrm{X}_{1}-0.51 \mathrm{X}_{2} ; \mathrm{R}^{2}=0.66$. Stepwise multiple regression also revealed that $\mathrm{Sm}$ was the only environmental factor that interacted with EI $(\hat{Y}=7.89-$
7.91X, $\left.R^{2}=0.2\right)$; while Sm $\left(X_{1}\right)$, windspeed $\left(X_{2}\right)$, average global radiation $\left(\mathrm{X}_{3}\right)$, minimum $\mathrm{RH}\left(\mathrm{X}_{4}\right)$ and rainfall $\left(\mathrm{X}_{5}\right)$ significantly influenced ERI according to the equation $\hat{\mathrm{Y}}$ $=198.79-158.25 \mathrm{X}_{1}-9.86 \mathrm{X}_{2}-0.29 \mathrm{X}_{3}-1.64 \mathrm{X}_{4}-0.08 \mathrm{X}_{5}$ $\left(\mathrm{R}^{2}=0.63\right)$. The summary of the influence of the climatic variables on the seedling emergence traits as obtained from stepwise multiple regression is contained in Table 5.

Although Sm had direct effect on $\mathrm{E} \%$ at 7 DAS, temperature and the heat changes in the soil (SHF) seemed to have exerted greater influence on $\mathrm{E} \%$ than soil moisture availability (Figures $1-4$ ), because SHF had a direct effect on $\mathrm{E} \%$ at 5 DAS, while minimum air temperature influenced E \% at 7 DAS alongside Sm. This is the only significant effect (direct or indirect) of Sm on E \%. Furthermore, $\mathrm{E} \%$ at 9 DAS was again directly influenced by SHF and minimum air temperature. The secondary climatic variables that interacted with the primary variables to affect $\mathrm{E} \%$ were mostly air temperature and radiation. 
Emergence \% at 5 DAS

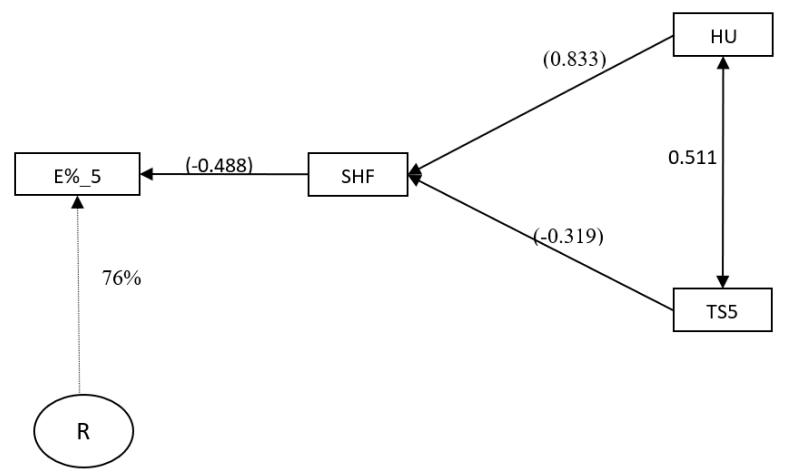

Figure 1: Sequential path-coefficient analysis diagram of climatic variables affecting emergence percent at 5 DAS. One directional arrows indicate direct effects while double arrows are correlation coefficients.

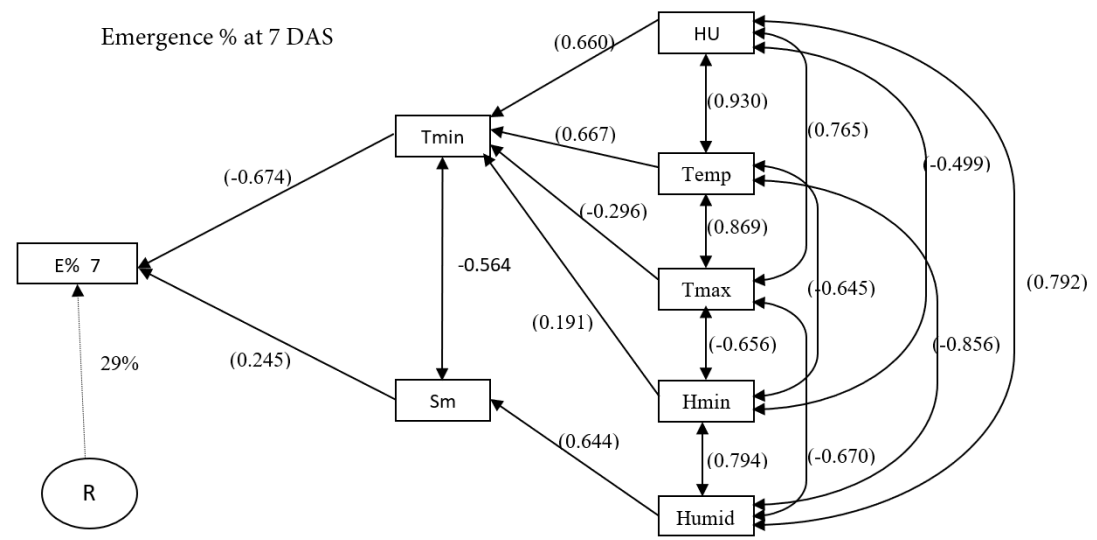

Figure 2: Sequential path-coefficient analysis diagram of climatic variables affecting emergence percent at 7 DAS. One directional arrows indicate direct effects while double arrows are correlation coefficients.

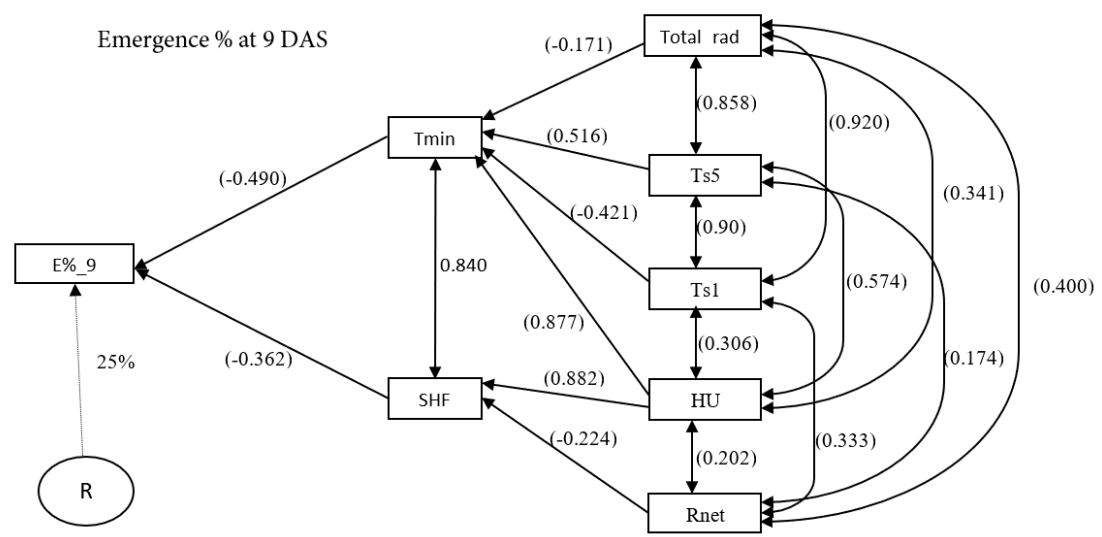

Figure 3: Sequential path-coefficient analysis diagram of climatic variables affecting emergence percent at 9 DAS. One directional arrows indicate direct effects while double arrows are correlation coefficients. 


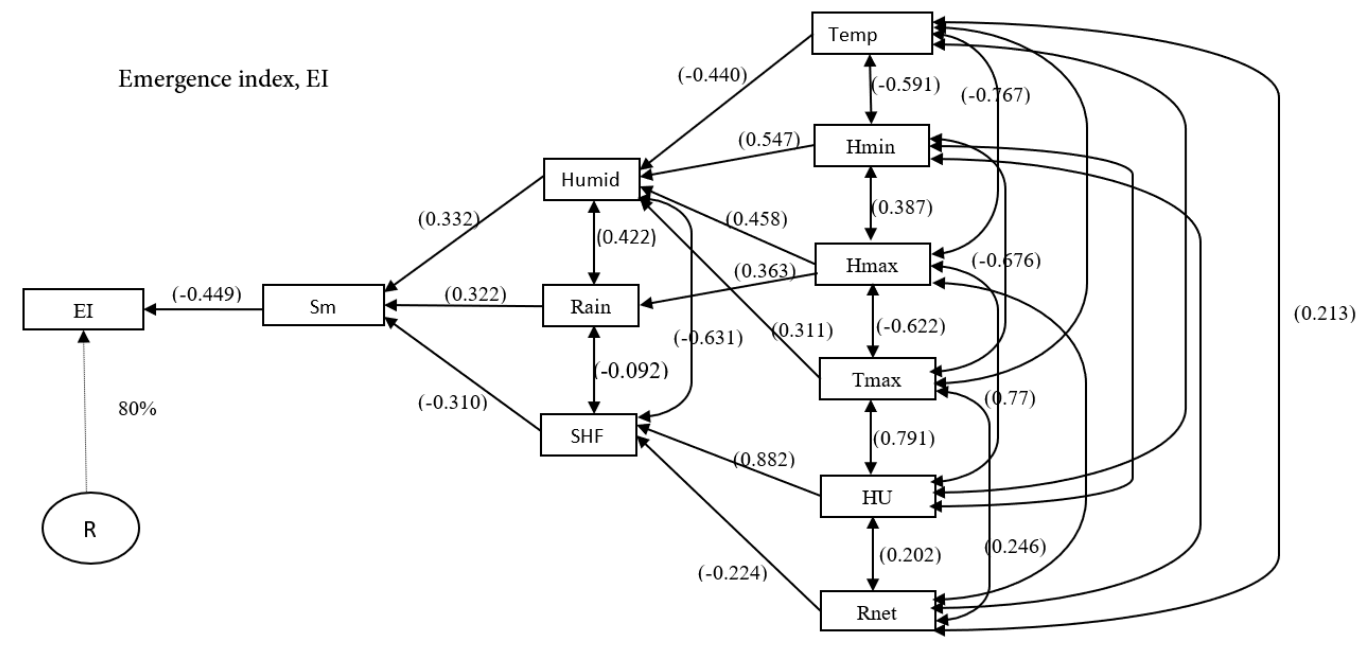

Figure 4: Sequential path-coefficient analysis diagram of climatic variables on emergence index. One directional arrows indicate direct effects while double arrows are correlation coefficients.

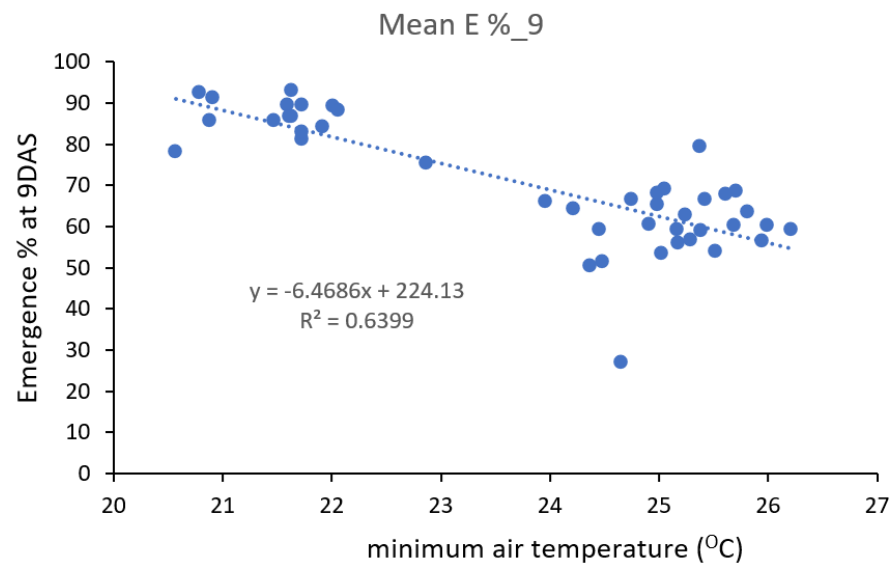

Figure 5: Response of emergence percentage to minimum air temperature for five maize varieties evaluated in 54 environments at the OAU TRF in 2016 and 2017 cropping seasons.

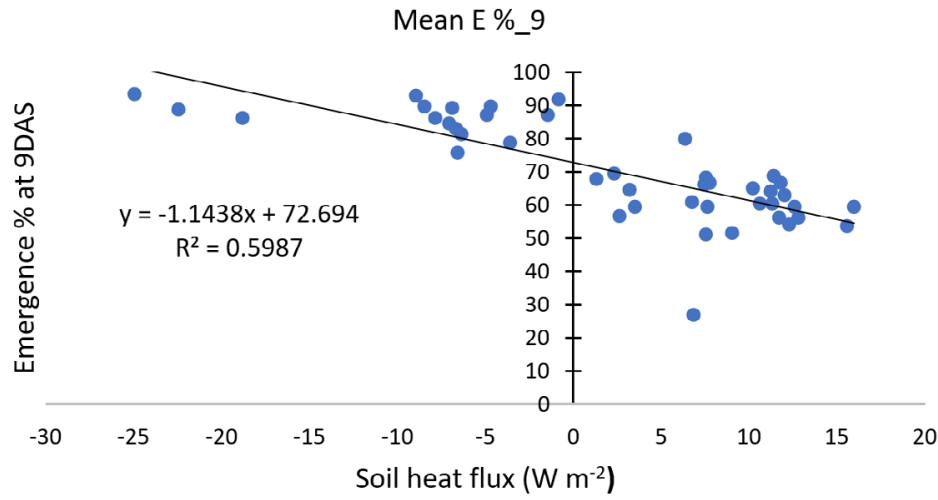

Figure 6: Response of emergence percentage to soil heat flux for five maize varieties evaluated in 54 environments at the OAU TRF in 2016 and 2017 cropping seasons. 
However, Figure 4 showed that EI, which represents the speed of emergence, was directly influenced by Sm. The secondary (indirect) effect of SHF $(\mathrm{P}=-0.310)$ was again observed on EI alongside mean RH $(\mathrm{P}=0.332)$ and rainfall $(\mathrm{P}=0.322)$ (Figure 4$)$. Emergence was found to occur at minimum air temperature range of $20{ }^{\circ} \mathrm{C}$ to $26^{\circ} \mathrm{C}$; and SHF range of -25 to $16 \mathrm{~W} \mathrm{~m}^{-2}$ but the optimum range was 21 to $22{ }^{\circ} \mathrm{C}$ for Tmin and -25 to $0 \mathrm{~W} \mathrm{~m}^{-2}$ for SHF (Figures 5 and 6).

\section{DISCUSSION}

The objective of this study was to investigate the effect of climatic factors, which are important factors of the environment, on maize seedling emergence in the rainforest agro-ecology of Southwestern Nigeria as typified by OAU TRF. Results of the ANOVA, showed highly significant mean squares for the environment source of variation for all seedling traits, accounting for up to $56 \%$ of the total sum of squares in some cases. This suggests that the environment, which greatly influenced seedling emergence of maize varieties in this and other studies (see inter alia Fakorede, 1984; Fakorede and Agbana, 1983) needs serious research attention.

Emergence \% in arable crops generally respond negatively to higher temperature, heat unit and soil heat flux (SHF); and positively to soil and air humidity. In the present study, E \% had significant positive correlation with soil moisture but not with rainfall. This was contrary to expectation because rainfall was the only source of moisture at the location of this study and, therefore, the only source of the moisture available in the soil. However, other climatic factors with considerable influence on soil moisture such as temperature, humidity and heat flux as well as soil properties, such as the soil structure and water holding capacity, may have played a part in the observed results. It is not the amount of water received through rainfall, but the amount of soil moisture available for plant growth that is important. It would seem, therefore, that climatic factors that influence the amount of water retained in the soil, such as humidity and temperature, are more important to crops than the amount of water that enters the soil through rainfall. Emergence index and ERI generally showed an opposite trend to that observed in E \%. This is expected because the negative correlations of EI and ERI with E \% has been widely reported in the literature (Fakorede and Ojo, 1981; Fakorede and Agbana, 1983; Fayose and Fakorede, 2014). The relatively weaker correlations (compared to temperature variables) and the vastly low $\mathrm{R}^{2}$ value where there was significant effect of Sm on seedling growth, suggests that $\mathrm{Sm}$ is not the most important environmental factor af- fecting maize seedling emergence in the rainforest. Contrary to the general belief, temperature and heat transfer in and around the seedlings could be more important if they reach a threshold (minimum air temperature above $23{ }^{\circ} \mathrm{C}$, and soil heat flux above $0 \mathrm{~W} \mathrm{~m}^{-2}$ in this study) irrespective of the amount of moisture available in the soil.

Spurious correlation is also common where climatic variables are involved because of the complex interactions that exist among them. Fakorede and Opeke (1985) described spurious correlation as a relationship between two variables, $a$ and $b$, in which $r_{a b}$ results largely from the fact that $a$ varies along with some other variable $c$ which, indeed, is the true predictor of $b$. This is an aspect where most of the previous studies fell short as they depended largely on correlation for data analysis and interpretation. Therefore in this study, path coefficient analysis was used in addition to correlation and regression analyses to determine the true effect of climatic factors on maize seedling emergence. Results of path analyses implicated minimum air temperature and soil heat flux as influencing emergence much more than soil moisture per se. The two air temperature variables directly influenced $\mathrm{E} \%$ negatively at 9 DAS and, in addition, soil heat flux had negative direct impact on $\mathrm{E} \%$ at 5 DAS. This suggest that heat transferred at night caused an effect on maize growth at the early stage. Perhaps, the soil temperature gradient created by low air temperature caused the soil to radiate the heat accumulated during the day, thereby causing an effect on the maize seedlings in the process. The thermal exchange processes at the soil surface is dominated by the meteorological conditions and occur by radiation, conduction, and convection, with or without phase changes. The thermal soil properties are strongly dependent on water content and many processes occurring in soils are strongly influenced by temperature (Tokoro et al., 2016). Soil moisture had a direct positive impact on $\mathrm{E} \%$ at 7 DAS even though the negative effect of minimum air temperature was even more pronounced. Results also revealed that, although soil moisture had a negative direct effect on EI, the ambit of influence might be limited because of the low $\mathrm{R}^{2}$ (about $20 \%$ ), with soil heat flux negatively influencing EI at the secondary level of interaction. This suggests that increased soil moisture might speed up the rate of emergence if other variables were not interacting.

It is a known fact that moisture is necessary for germination. In the present study, seeds sown in March for the first environment in 2017 stayed in the soil for up to three weeks and only emerged following the first rainfall. Unfortunately, climatic variables are in constant interaction; therefore, the benefits of moisture for seedling growth is seemingly masked when it is not at a critical level. Also, 2017 had poorer seedling growth 
performance compared to 2016, a result attributable to the air temperature/soil heat flux interaction, because of the smaller rainfall in 2017 (675 $\mathrm{mm}$ in 2017 vs more than $1000 \mathrm{~mm}$ in 2016 ) and consequently, higher air temperature (average value of $28.5^{\circ} \mathrm{C}$ in 2017 vs $25.8^{\circ} \mathrm{C}$ in 2016). One could theorize, therefore, that soil heat transfer occurring at night raises night air temperature around maize seedlings, thereby negatively affecting the seedlings, even though Sm remains at an adequate level; or that seedling growth will proceed at an optimum level with Sm level that is just sufficient, as long as soil heat and heat transfer are minimized especially in the early hours of the day. It is also noteworthy that most of the variables that affected $\mathrm{E} \%$ indirectly via the first order variables were air temperature and radiation. Even though there was no direct relationships of the seedling emergence and vigour traits with yield, in agreement with some earlier studies (Fayose and Fakorede, 2014; Fakorede and Agbana, 1983; Fakorede and Ojo, 1981), it is however incontrovertible, that the seedling traits strongly influence yield, albeit, indirectly. For instance, severe and prolonged water stress at the seedling stage may damage the structure of the photosynthetic membrane resulting in lower chlorophyll content and thus, low radiation use efficiency (RUE, Song et al., 2019). Maize plant with such damage often did not show meaningful recovery irrespective of the amount of moisture supplied at the latter stages. Therefore, unrecoverable yield loss could occur if adequate attention is not paid to growth at the seedling stage. Also, high final stands, tolerance to infestation by pests and diseases, less likelihood of lodging, increased efficiency of interception of solar radiation for photosynthesis, and reduced need for weed control (when canopies touch) are some of the strong benefits of ensuring that climatic conditions are favourable for maize at the seedling stage that have been well documented in the literature (Li et al., 2015; Fayose et al., 2021).

\section{CONCLUSIONS}

Despite the wide recognition of the importance of soil moisture to seed germination and seedling emergence, soil heat flux, minimum air temperature and the interactions between them were more important, although Sm favours higher speed of emergence. Emergence occurred at minimum air temperature range of $20{ }^{\circ} \mathrm{C}$ to $26^{\circ} \mathrm{C}$; and SHF range of -25 to $16 \mathrm{~W} \mathrm{~m}^{-2}$ but the optimum air Tmin and SHF for emergence were 21 to $22{ }^{\circ} \mathrm{C}$ and -25 to $0 \mathrm{~W} \mathrm{~m}^{-2}$, respectively. Also, soil moisture, rather than rainfall, is the important factor for maize seedling emergence, despite the general recognition of rainfall as an important factor for agriculture in the rainforest ecologies. Consequently, any agronomic practices that would conserve soil moisture would be of benefit to maize at the seedling stage.

\section{REFERENCES}

Abasi, L., Fakorede, M. A. B. and Alofe, C. O. (1985). Comparison of heat units and calendar days for predicting silking dates in maize in a tropical rainforest location. Maydica, 30, 15-30. https://doi.org/10.1017/S0014479700012217

Alm, D.M., Stoller, E.W. and Wax, L.M. (1993). An index model for predicting seed germination and emergence rates. Weed Technology, 7, 560-69. https://doi.org/10.1017/ S0890037X00037349

Ammani, A. A., Ja'afaru, A. K., Aliyu, J. A. and Arab, A. I. (2012). Climate change and maize production: empirical evidence from Kaduna State, Nigeria. Journal of Agricultural Extension, 16(1), 1-8. https://doi.org/10.4314/jae.v16i1.1

Awosanmi, F. E., Ajayi, S. A. and Menkir, A. (2016). Impact of moisture stress on seed yield in tropical maize. International Journal of Agricultural Innovation and Research, 4(6), 1033-1038.

Badu-Apraku, B., Akinwale, R. O. and Oyekunle, M. (2014). Efficiency of secondary traits in selecting for improved grain yield in extra-early maize under Striga-infested and Strigafree environments. Plant Breeding. doi:10.1111/pbr.12163. https://doi.org/10.1111/pbr.12163

Dimpsey, R. (1995). Sweet corn production. Agriculture notes. State of Victoria, Department of Primary Industries, Australia.

Fakorede, M.A.B. (1985). Response of maize to planting dates in a tropical rainforest location. Experimental Agriculture, 21, 19-30. https://doi.org/10.1017/S0014479700012217

Fakorede, M. A. B. and Akinyemiju, O. A. (2003). Climate change: effects on maize production in a tropical rainforest location. P. 272-282. In Badu-Apraku, B., Fakorede, M. A. B., Ouedraogo, M., Carsky, R.J. and Menkir, A. (Eds.). Maize revolution in West and Central Afica. Proceedings of a Regional Maize Workshop, IITA-Cotonou, Benin Republic. 14-18 May 2001. WECAMAN/IITA.

Fakorede, M. A. B. and Ojo, D. K. (1981). Variability for seedling vigour in maize. Experimental Agriculture, 17, 195-201. https://doi.org/10.1017/S0014479700011455

Fakorede, M. A. B. and Agbana, S. B. (1983). Heterotic effects and association of seedling vigor with mature plant characteristics and grain yield in some tropical maize cultivars. Maydica, 28, 327-338.

Fakorede, M. A. B and Opeke, B. O. (1985). Weather factors affecting the response of maize to planting dates in a tropical rainforest location. Experimental Agriculture, 21, 31-40. https://doi.org/10.1017/S0014479700012229

FAO, (2016). FAOSTAT. Food and Agricultural Organization of the United Nations, Rome, Italy. http://www.fao.org/faostat/en/\#rankings/countries_by_commodity

Fayose, C. A. and Fakorede M. A. B. (2014). Growth analysis of maize varieties at the seedling and vegetative developmental stages. Proceedings of the 38th Annual Conference of 
the Genetics Society of Nigeria, Benin, Edo State, Nigeria. 19-23rd October. Pp 453-459.

Fayose, C. A. and Fakorede M. A. B. (2021). Planting date effects on maize growth and development in a rainforest agroecological location of Southwestern Nigeria. Acta Agriculturae Slovenica, 117(1), 101-109. https://doi.org/10.14720/ aas.2021.117.1.1297

Fayose, C. A., Fakorede M. A. B., Badu-Apraku, B. and Menkir, A. (2021). Canopy architecture and grain yield of maize in the rainforest of Southwestern Nigeria. Manuscript submitted to Experimental Agriculture.

Jong, S. K., Brewbaker, J. L. and Lee, C. H. (1982). Effects of solar radiation on the performance of maize in 41 successive monthly plantings in Hawaii. Crop Science, 22, 13-18. https://doi.org/10.2135/cropsci1982.0011183X0022000100 $04 \mathrm{x}$

Li, C., Li, Y., Shi, Y., Song, Y., Zhang, D., Buckler, E. S., Zhang, Z., Wang, T. \& Li, Y. (2015). Genetic control of the leaf angle and leaf orientation value as revealed by ultra-high density maps in three connected maize populations. PLOS One Journal, 10(3), e0121624. https://doi.org/10.1371/journal. pone. 0121624

Mohammadi, S.A., Prasanna, B.M., and Singh, N.N. (2003). Sequential path model for determining interrelationship among grain yield and related characters in maize. Crop
Science, 42, 1690-1697. https://doi.org/10.2135/cropsci2003.1690

Oke, O. F. (2016). Effects of agro-climatic variables on yield of Zea mays L. in a humid tropical rainforest agroecosystem. Journal of Environment and Earth Science, 6(1), 22-30.

SAS Institute Inc. (2000). "Base SAS ${ }^{\circledR} 9.0$ Procedures Guide." Cary, NC: SAS Institute Inc.

Song, L., Jin, J. \& He, J. (2019). Effect of severe water stress on maize growth process in the field. Sustainability, 11, 1-18 https://doi.org/10.3390/su11010001

SPSS Inc. (2007). SPSS Base 17.0 for windows user's guide. SPSS Inc., Chicago, USA.

Talabi, A. O., Badu-Apraku, B. and Fakorede, M. A. B. (2017). Genetic variances and relationship among traits of an early maturing maize population under drought-stress and low nitrogen environments. Crop Science, 57, 681-692. https:// doi.org/10.2135/cropsci2016.03.0177

Tokoro, T. Ishikawa, T., Shirai, S. and Nakamura, T. (2016). Thermal conductivity of sandy soil with electrical characteristics. Soils and Foundation, 56(5), 927-936. https://doi. org/10.1016/j.sandf.2016.08.016

Tunde, A. M., Usman, B. A. and Olawepo, V. O. (2011). Effects of climatic variables on crop production in Patigi L. G. A., Kwara State, Nigeria. Journal of Geography and Regional Planning, 4(14), 695-700. 